\title{
PERANAN DINAMIKA OSEANOGRAFI DALAM PENGELOLAAN SUMBER DAYA PERIKANAN
}

\author{
Nining Sari Ningsih ${ }^{\text {a,* }}$, Farrah Hanifah ${ }^{\text {a }}$, Amelia Mustika Kusmarani ${ }^{\text {b }}$ \\ ${ }^{a}$ Kelompok Keahlian Oseanografi, Fakultas Ilmu dan Teknologi Kebumian, Institut Teknologi Bandung, Jl. \\ Ganesha 10, Bandung 40132, Indonesia \\ ${ }^{\mathrm{b}}$ Program Studi Oseanografi, Fakultas Ilmu dan Teknologi Kebumian, Institut Teknologi Bandung, Jl. Ganesha \\ 10, Bandung 40132, Indonesia
}

*Koresponden penulis: nining@ fitb.itb.ac.id

\begin{abstract}
Abstrak
Dinamika oseanografi di perairan Indonesia seperti arus, front, eddy (a.l., terkait dengan shear velocity dan penjalaran gelombang Rossby), kedalaman termoklin, serta upwelling berdampak pada kesuburan perairan dan selanjutnya akan mempengaruhi pola migrasi, daerah pemijahan, dan kelimpahan ikan pelagis. Selain itu, variabilitas iklim dalam skala waktu intramusiman, musiman, antartahunan, hingga intradecadal, decadal, dan interdecadal berperan terhadap dinamika oseanografi, kesuburan suatu perairan, dan kelimpahan ikan pelagis baik secara spasial maupun temporal. Model hidrodinamika tiga dimensi (3D) yang dikenal dengan sebutan HYbrid Coordinate Ocean Model (HYCOM) digunakan dalam penelitian ini untuk mensimulasikan dinamika elevasi, arus, serta temperatur air laut baik secara spasial (horizontal dan vertikal) maupun temporal. Simulasi model dilakukan selama \pm 64 tahun $(1950$ - 2013) di perairan Indonesia untuk mengetahui variabilitas dan tren jangka panjang perubahan parameter oseanografi yang terjadi akibat perubahan iklim (terkait dengan pemanasan global). Hasil studi ini berguna bagi pengelolaan perikanan, khususnya dapat digunakan sebagai informasi dasar untuk memprediksi pola migrasi ikan pelagis (a.l., tuna) dan kedalaman alat pancing.
\end{abstract}

Kata kunci: dinamika oseanografi, model hidrodinamika 3D, tren, variabilitas iklim

\begin{abstract}
Oceanographic dynamics in Indonesian seas, such as currents, front, eddy related with shear velocity and Rossby wave propagation, thermocline depth, and upwelling phenomenon have a great impact on sea water fertility and in turn will also affect migration pattern, spawning ground, stock abundance of pelagic fishes. In addition, climate variability from intraseasonal, seasonal, interannual, intradecadal, decadal and even longer timescales play an important role in the oceanographic dynamics, sea water fertility, and abundance of pelagic fish stock both spatially and temporally. In this study, a three-dimensional (3D) hydrodynamic model called the HYbrid Coordinate Ocean Model (HYCOM) has been applied to simulate spatial (horizontally and vertically) and temporal dynamics of free surfave elevation, currents, and sea temperature. The HYCOM has been run for the period of 64 years (1950-2013) within the Indonesian waters to investigate variability and long term trend of changes of oceanographic parameters affected by climate changes with regard to global warming. These study results are important in fisheries management, especially where they can be used to provide basic information in predicting the migration pattern of pelagic fishes (e.g., tuna) and fishing pole locations over depth.
\end{abstract}

Keywords: Oceanographic dynamics, a 3D hydrodynamic model, trend, climate variability

\section{PENDAHULUAN}

Ikan pelagis merupakan kelompok ikan yang hidup di permukaan dan kolom perairan laut dan dapat dibagi menjadi 2 (dua) jenis, yaitu ikan pelagis kecil dan ikan pelagis besar. Tuna merupakan salah satu contoh jenis ikan pelagis besar yang bernilai komersial tinggi dan di pasar global permintaannya selalu meningkat. Dari sektor perikanan, selain udang, tuna merupakan salah satu penghasil devisa negara terbesar di Indonesia. Di perairan Indonesia [1], Laut Banda dan perairan selatan Jawa diketahui sebagai daerah yang potensial untuk fishing ground tuna baik yang berjenis besar (madidihang, tuna mata besar, albacora, dan tuna sirip biru selatan) maupun kecil (cakalang dan tongkol). Kegiatan penangkapan tuna di perairan Indonesia yang dilakukan oleh perusahaan 
penangkap tuna domestik maupun yang secara ilegal dilakukan oleh kapal asing (a.l., Thailand, Philipina, Korea, dan Jepang) dirasakan semakin kompetitif sehingga memerlukan teknik-teknik penangkapan yang efisien (hemat waktu dan bahan bakar) serta hasilnya optimal. Untuk itu, diperlukan pengetahuan kondisi parameter oseanografi yang berguna untuk memprediksi keberadaan ikan pelagis tersebut.

Kondisi parameter oseanografi dan daerah yang kaya makanan sangat mempengaruhi keberadaan ikan pelagis di suatu perairan, karena sifatnya yang senang bermigrasi untuk memburu daerah yang kaya makanan (daerah upwelling), senang hidup di daerah front (pertemuan) antara massa air hangat dan air dingin, serta senang hidup pada kisaran suhu dan kedalaman tertentu [2], a.l.: cakalang $\left(17-28^{\circ} \mathrm{C}\right)$, tuna sirip biru $(12-25$ $\left.{ }^{\circ} \mathrm{C}\right)$, tuna mata besar $\left(11-28{ }^{\circ} \mathrm{C}\right)$, madidihang $\left(18-31{ }^{\circ} \mathrm{C}\right)$, dan albacora $\left(14-23{ }^{\circ} \mathrm{C}\right)$. Selain itu, ikan tuna senang bermigrasi tidak hanya dalam arah horizontal tetapi juga dalam arah vertikal. Migrasi dilakukan dalam rangka pemijahan (bertelur) dan penyesuaian diri terhadap perubahan faktor lingkungan perairan (khususnya suhu, oksigen, dan faktor kelimpahan makanan) yang dipengaruhi oleh variabilitas iklim baik dari skala intramusiman (20 - 100 hari), musiman (6 bulan dan 12 bulan), antartahunan ( 2 - 7 tahun), maupun sampai dengan intradecadal (7 - 9 tahun), decadal (10 - 11 tahun), dan interdecadal (16 - 18 tahun).

Ikan tuna jenis yellowfin dan bigeye melakukan migrasi vertikal setiap hari [3]. Yellowfin pada siang hari akan bermigrasi ke lapisan dalam pada kisaran kedalaman 50 $100 \mathrm{~m}$ dan suhu $19-23{ }^{\circ} \mathrm{C}$, dan pada malam hari akan bermigrasi ke lapisan permukaan (kedalaman 0 - $50 \mathrm{~m}$; suhu $25-26{ }^{\circ} \mathrm{C}$ ). Sementara itu, bigeye pada siang hari akan bermigrasi ke lapisan dalam $(100-350 \mathrm{~m})$ dengan suhu $10-15^{\circ} \mathrm{C}$ dan pada malam hari akan bermigrasi ke lapisan atas pada kedalaman $0-75 \mathrm{~m}$ dengan suhu $23-25{ }^{\circ} \mathrm{C}$. Berdasarkan uraian tersebut terlihat pentingnya informasi distribusi suhu sebagai fungsi dari kedalaman di suatu perairan yang tentunya sangat dipengaruhi oleh variabilitas iklim. Informasi variasi suhu secara vertikal dan kedalaman termoklin (lapisan air laut dimana terjadi penurunan suhu yang cepat terhadap kedalaman, sebesar $\pm 0,1{ }^{\circ} \mathrm{C} / \mathrm{m}$ ) sangat penting untuk penentuan kedalaman alat pancing tuna (long line). Dalam hal ini kedalaman (penetrasi) mata pancing merupakan salah satu faktor yang sangat penting untuk mendapatkan hasil tangkapan yang maksimum [1].

Selain daerah upwelling, front juga merupakan lokasi yang disukai ikan pelagis karena merupakan lokasi yang kaya akan makanan yang disebabkan oleh beberapa faktor, seperti: (1) adanya akumulasi plankton yang disebabkan konvergensi, (2) proses percampuran (mixing) yang menyebabkan tingginya produktivitas primer di daerah tersebut [4]. Fronts terbentuk karena berbagai faktor dinamis yang terjadi di suatu perairan, seperti arus, tidal mixing, turbulent eddies, upwelling, dan internal waves [5]. Kondisi oseanografi di perairan Indonesia seperti arus, front, eddy (a.l., terkait dengan shear velocity dan penjalaran gelombang Rossby), kedalaman termoklin, upwelling dan kaitannya dengan kesuburan perairan tergantung pada variabilitas iklim. Eksistensi pengaruh variabilitas iklim terhadap kondisi oseanografi di perairan Indonesia, khususnya untuk skala musiman dan antartahunan (El Niño-Southern Oscillation/ENSO dan Indian Ocean Dipole/IOD), telah dikonfirmasi dalam beberapa studi terdahulu [a.1., 6, 7, 8, dan 9]. Namun demikian, pengaruh variabilitas iklim dalam skala waktu intramusiman, intradecadal, decadal, dan interdecadal terhadap dinamika oseanografi serta tren jangka panjangnya di perairan Indonesia dan lebih lanjut dikaitkan dengan tingkat kesuburan perairan masih terbatas.

Pada makalah ini dibahas parameterparameter apa saja di dalam dinamika oseanografi yang berperan dalam pengelolaan sumber daya perikanan. Pemahaman dinamika oseanografi yang baik di suatu perairan baik secara spasial maupun temporal dapat digunakan sebagai dasar untuk menyediakan informasi yang berguna bagi industri penangkapan ikan pelagis dalam rangka memperoleh hasil tangkapan yang optimum 
dan efisien (hemat bahan bakar, waktu, dan biaya). Selain itu, pengetahuan tentang tren jangka panjang dari parameter oseanografi sangat diperlukan untuk adaptasi dan antisipasi sistem pangan terhadap perubahan iklim.

\section{MATERI DAN METODE}

Metode utama yang digunakan dalam paper ini untuk membahas peranan dinamika oseanografi dalam pengelolaan sumber daya perikanan adalah pemodelan hidrodinamika dan transpor temperatur tiga dimensi (3D) yang meliputi perhitungan elevasi, arus, serta distribusi temperatur baik secara spasial (horizontal dan vertikal) maupun temporal yang hasilnya dapat digunakan sebagai dasar untuk memprediksi pola migrasi ikan pelagis (a.l., tuna) dan kedalaman alat pancing dengan memperhatikan faktor variabilitas dan perubahan iklim.

Model hidrodinamika 3D yang digunakan adalah HYbrid Coordinate Ocean Model (HYCOM) yang dikembangkan oleh Naval Research Laboratory of USA [10] dan diasimilasi dengan data suhu permukaan laut. Di dalam model ini digunakan gabungan beberapa koordinat vertikal, yaitu kooordinat vertikal isopiknal untuk laut terbuka dan terstratifikasi, koordinat vertikal sigma untuk laut dangkal, dan koordinat vertikal $z$ untuk laut yang sangat dangkal serta di lapisan percampuran atau terstratifikasi lemah di laut terbuka. Simulasi model dilakukan dalam jangka panjang, yaitu selama \pm 64 tahun (1950 - 2013) untuk mengetahui tren perubahan parameter oseanografi yang terjadi akibat perubahan iklim yang disebabkan faktor pemanasan global. Keluaran (output) model yang dianalisis adalah elevasi permukaan laut (sea surface height), kecepatan arus horizontal dan vertikal, serta temperatur laut.

Sebagai data pendukung, untuk keperluan analisis variabilitas intramusiman digunakan data Indeks MJO (Madden Julian Oscillation), outgoing longwave radiation (OLR), dan kecepatan angin zonal yang diproduksi oleh the Australian Government Bureau of Meteorology (BOM) dan National
Oceanic and Atmospheric Administration (NOAA). Untuk analisis variabilitas musiman, digunakan data kecepatan angin dari NCEP (National Centers for Environmental Prediction). Selain itu, untuk analisis variabilitas antartahunan, nilai the Oceanic Niño Index(ONI) dan Dipole Mode Index (DMI) masing-masing digunakan sebagai indikator kejadian ENSO dan IOD, sedangkan untuk sinyal intradecadal-decadal digunakan annual PDO (Pacific Decadal Oscillation) Index. Indeks ONI, DMI, dan PDO tersebut diperoleh dari NOAA.

\section{HASIL DAN PEMBAHASAN}

\section{Pengaruh Variabilitas Iklim}

\section{Intramusiman}

Salah satu fenomena intramusiman yang mempengaruhi dinamika oseanografi adalah MJO yang merupakan fenomena atmosfer di daerah tropis berupa penjalaran pusat awan konvektif ke arah timur di sepanjang ekuator dalam rentang $10{ }^{\circ} \mathrm{LU}$ hingga $10^{\circ} \mathrm{LS}$ dengan kecepatan rata-rata $5 \mathrm{~m} / \mathrm{det}$ dan periode $30-90$ harian [11]. Gambar 1a menunjukkan kejadian MJO dalam kurun waktu 2004-2006 yang ditandai dengan Indeks MJO > 2. Dalam makalah ini, pembahasan difokuskan pada kejadian MJO nomor 5 dan 6 (Gambar 1a) ketika masing-masing MJO tersebut berada pada Fase 3 (Samudra India bagian timur) dan Fase 4 (benua maritim bagian barat). Lokasi Fase 3 dan 4 tersebut ditandai dengan kotak merah pada Gambar 1b. Indikator adanya MJO tidak hanya dilihat dari nilai Indeks MJO tetapi juga dari nilai OLR, sedangkan pengaruhnya dianalisis berdasarkan nilai kecepatan angin zonal dan sea surface height anomaly (SSHA) di sepanjang transek pantai barat Sumatra hingga selatan Jawa - Nusa Tenggara (Gambar 1c).

Gambar 1d-1f masing-masing memperlihatkan diagram Hovmöller dari $O L R$, angin, dan SSHA di sepanjang transek pantai barat Sumatra hingga selatan Jawa Nusa Tenggara selama kejadian MJO ke-5 dan ke-6 (Gambar 1a). Dari Gambar 1d terlihat bahwa seiring dengan kejadian kedua MJO tersebut terdapat pergerakan nilai OLR 
negatif ke arah timur pada periode 6 Maret 11 April 2005 (MJO ke-5) dan 6 - 11 April (MJO ke-6). Pergerakan MJO ke arah timur ini (Gambar 1d) dapat membangkitkan downwelling Kelvin wave (DKW) yang menjalar di sepanjang pantai barat Sumatra
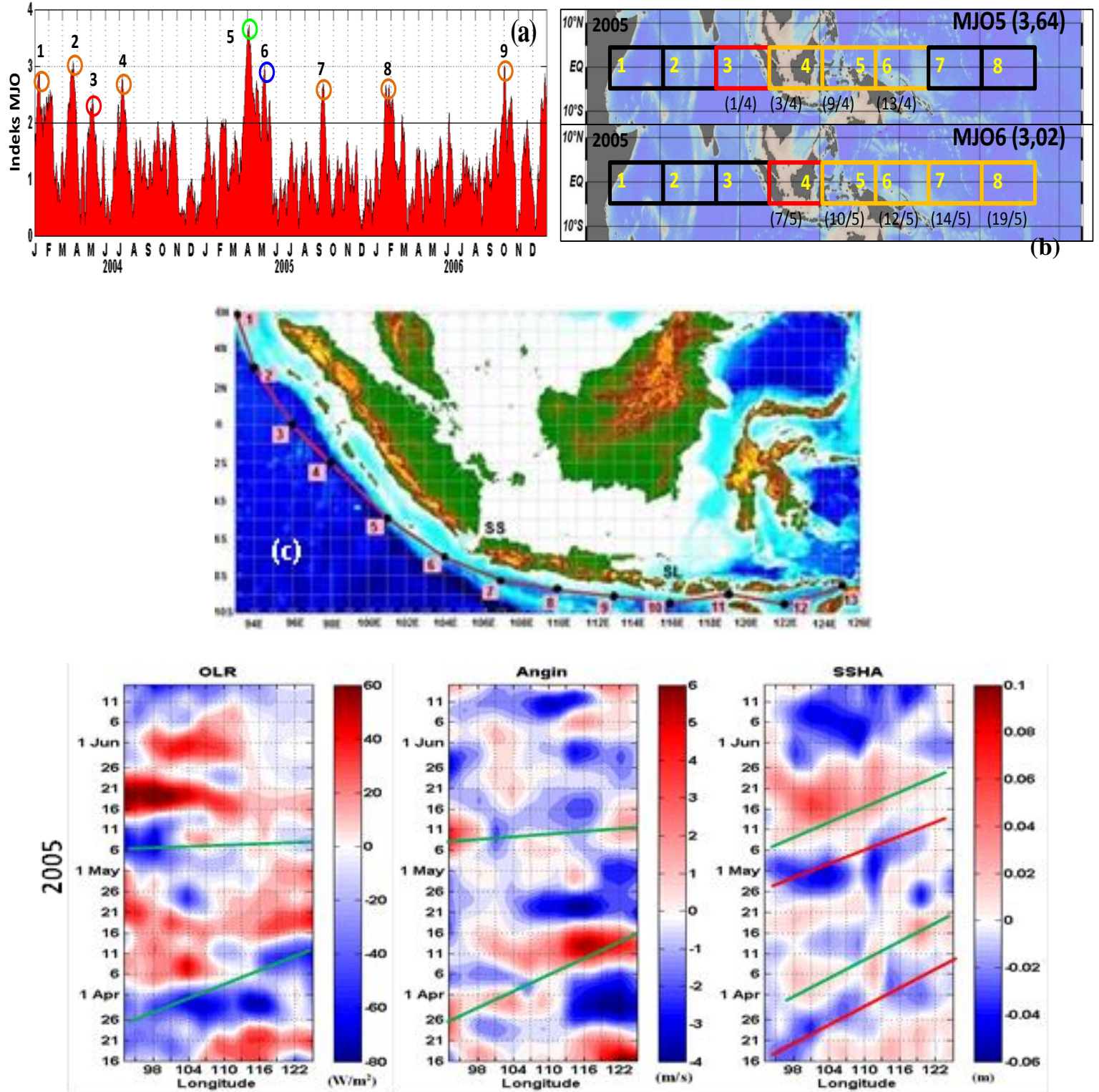

Gambar 1. (a). Indeks MJO dalam kurun waktu 2004-2006. Penelitian dilakukan pada waktu kejadian MJO ke-5 dan ke-6 (masing-masing ditandai dengan lingkaran warna hijau dan biru); (b). Posisi MJO ke-5 dan ke-6, masing-masing terjadi pada Fase 3 (Samudra India bagian timur) dan Fase 4 (benua maritim bagian barat), ditandai dengan kotak merah; (c). Lokasi pengambilan data OLR, angin zonal, dan SSHA di sepanjang pantai barat Sumatra dan selatan Jawa - Nusa Tenggara (Titik 1 - 13); (d)-(f) masingmasing nilai OLR, kecepatan angin zonal, dan SSHA di sepanjang transek. Garis hijau pada Gambar 1d-1f masing-masing menunjukkan pergerakan MJO, penguatan kecepatan angin zonal, dan penjalaran DKW. Garis merah pada Gambar if menunjukkan terjadinya penurunan permukaan laut berupa penjalaran UKW sebelum kedatangan DKW 
dan selatan Jawa - Nusa Tenggara yang ditandai dengan kenaikan permukaan air laut (SSHA positif pada Gambar 1f). Selain itu, eksistensi MJO ini juga diiringi dengan kenaikan kecepatan angin zonal (Gambar 1e).

Berdasarkan Gambar if terlihat bahwa sebelum DKW tiba di sepanjang daerah kajian (ditandai dengan garis hijau), maka sekitar 10 - 13 hari sebelumnya akan didahului dengan kejadian penurunan muka laut (ditandai dengan garis merah) berupa penjalaran upwelling Kelvin wave (UKW). Ditinjau dari sudut pandang aplikasinya dalam dunia perikanan, penurunan muka laut ini diduga kuat akan diiringi dengan naiknya termoklin (fenomena upwelling) dan selanjutnya berdampak dalam meningkatkan kesuburan perairan dan penentuan fishing ground yang optimum. Untuk mengkonfirmasi dugaan tersebut, diperlukan studi lebih lanjut dengan melakukan ujicoba lapangan dalam rangka mendapatkan data tangkapan ikan berdasarkan informasi keberadaan MJO pada suatu waktu serta UKW yang dibangkitkannya.

Gambar 2, menunjukkan analisis spektrum energi MJO dan SSHA di perairan selatan Jawa hingga Kepulauan Sunda Kecil (Titik $7-13$ yang terdapat sepanjang transek pada Gambar 1c). Hasil analisis spektrum energi tersebut memperlihatkan eksistensi sinyal intramusiman pada skala waktu 30 -
100 hari dengan energi yang lebih kecil jika dibandingkan sinyal musiman (6 dan 12 bulan). Walaupun energinya relatif lebih kecil, variabilitas intramusiman ini akan cukup signifikan dalam mempengaruhi perubahan parameter oseanografi (a.l., tinggi muka laut, arus, dan kedalaman termoklin) pada saat pengaruh monsun sedang minimum.

\section{Musiman}

Siklus musiman yang disebabkan angin monsun telah diketahui mempengaruhi dinamika oseanografi di perairan Indonesia [a.1., 12 dan 13], seperti perairan selatan Jawa yang akan menjadi fokus pembahasan pada tulisan ini. Gambar 3a dan 3b menunjukkan hasil simulasi nilai kecepatan arus vertikal rata-rata bulanan yang mewakili musim timur (September) dan musim barat (Desember). Dari gambar tersebut terlihat bahwa pada musim timur (Gambar 3a) terdapat kecepatan arus vertikal positif yang cukup signifikan di sekitar perairan pantai selatan Jawa dibandingkan pada musim barat (Gambar 3b). Hal ini disebabkan, pada musim timur, angin tenggara di perairan selatan Jawa akan menyebabkan transpor Ekman ke arah offshore, sehingga terjadi kekosongan massa di perairan pantai dan selanjutnya akan diganti dengan gerakan massa air ke atas (upwelling) yang ditunjukkan dengan
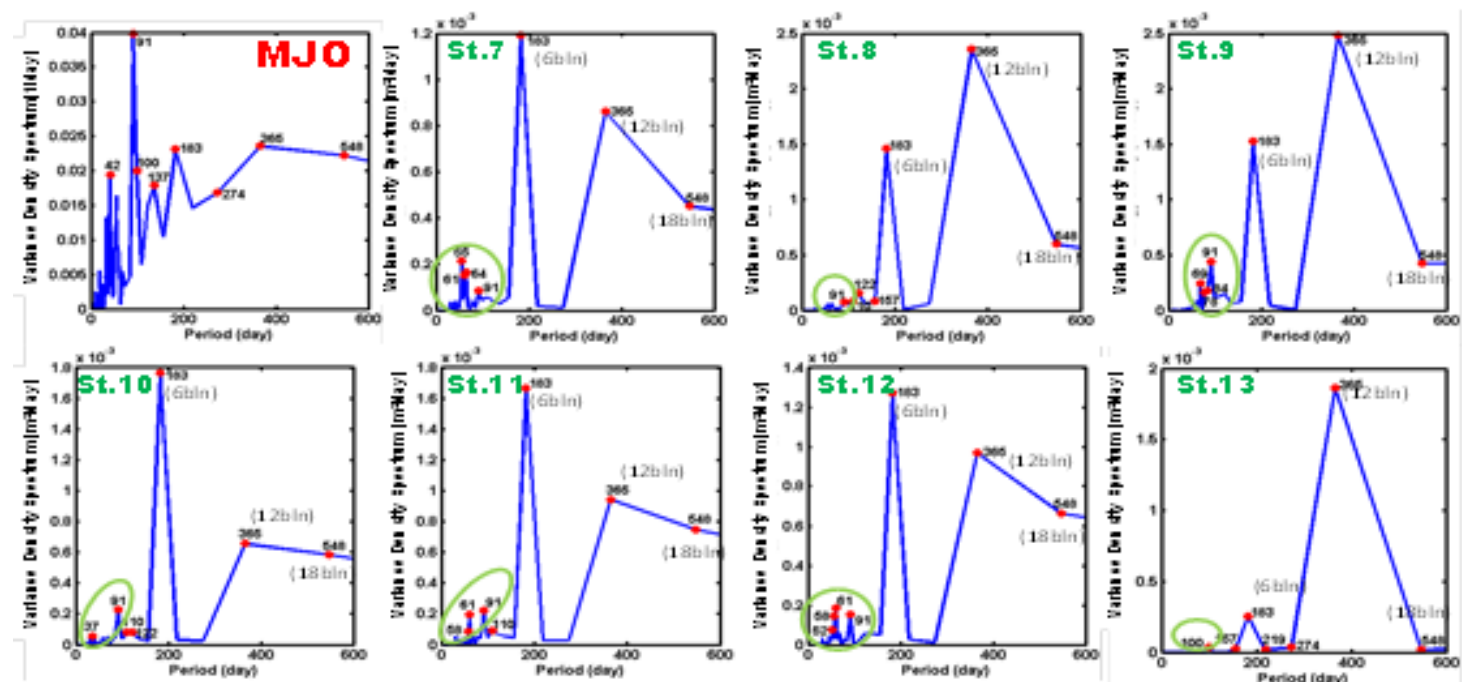

Gambar 2. Analisis Spektrum Energi MJO dan SSHA di perairan selatan Jawa dan Kepulauan Sunda Kecil (lokasi pengambilan data SSHA adalah Titik 7 - 13 pada Gambar 1c). 
kecepatan arus vertikal yang positif. Fenomena upwelling ini akan disertai dengan naiknya massa air dingin, sehingga temperatur permukaan laut menjadi lebih dingin dibandingkan daerah sekitarnya (Gambar 3c).

Sebaliknya, pada musim barat, angin barat laut menyebabkan penumpukkan massa air di perairan pantai selatan Jawa, sehingga terjadi downwelling (kecepatan arus vertikal vertikal negatif). Pada Gambar 3b, nilai kecepatan negatif digambarkan dengan warna yang sama dengan kecepatan vertikal positif yang sangat kecil dan mendekati nol karena dalam hal ini kecepatan vertikal yang dikaji (interest value) adalah yang bernilai positif (kejadian upwelling). Pada kejadian
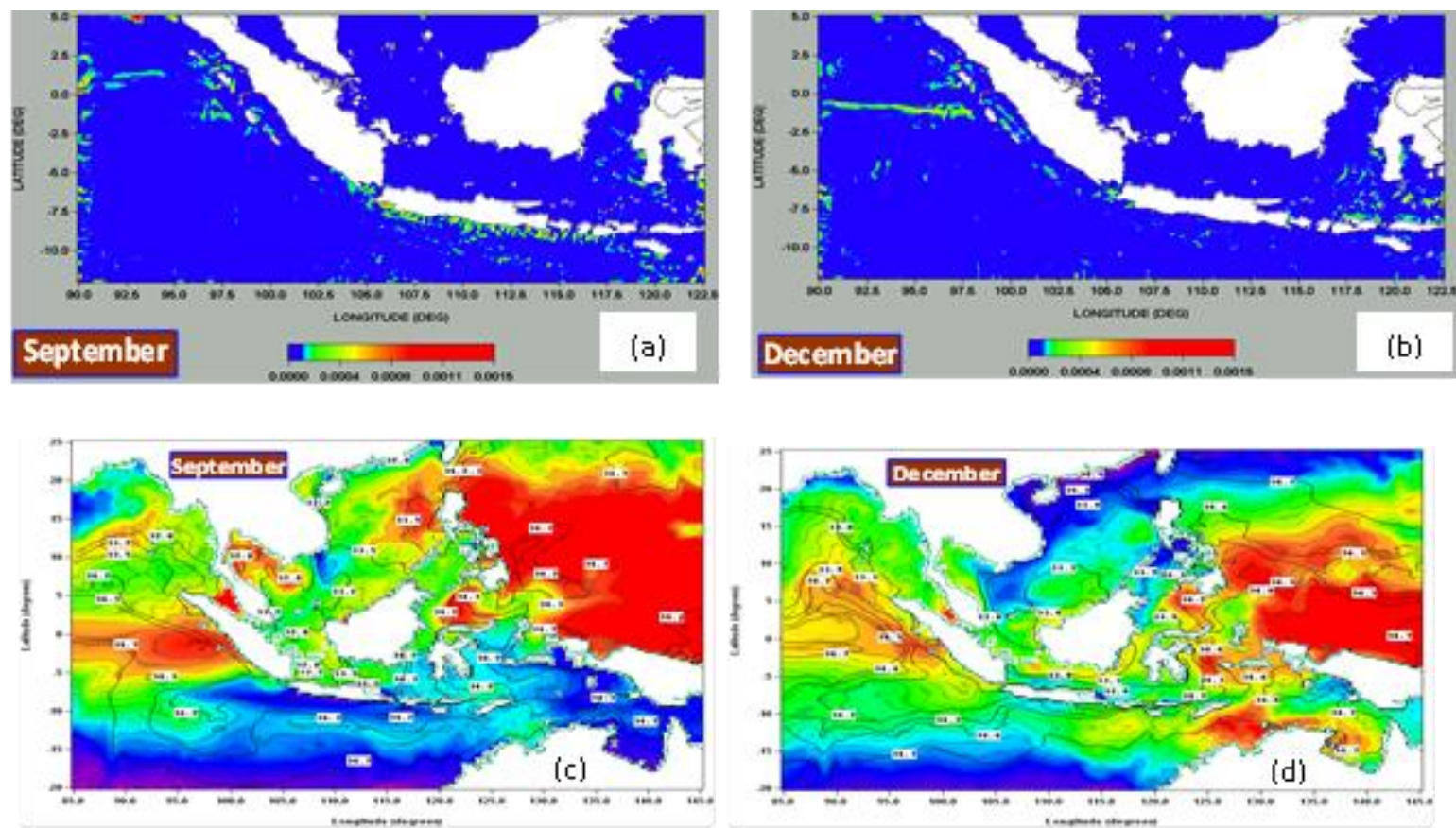

downwelling (penurunan massa air ke lapisan bawah), temperatur permukaan laut lebih tinggi dibandingkan ketika terjadi fenomena upwelling (Gambar 3d).

Kejadian upwelling pada musim timur yang ditandai dengan eksistensi kecepatan arus vertikal (Gambar 3a) berkorelasi dengan kesuburan perairan didukung dengan data tangkapan ikan yang relatif besar (Gambar 3e) pada musim timur (Juni, Juli, Agustus) dan musim peralihan dari timur ke barat (September dan Oktober). Sebaliknya pada musim barat, kekuatan upwelling melemah (Gambar 3b) ditandai dengan penurunan jumlah tangkapan ikan pada bulan Desember, Januari, dan Februari (Gambar 3e).

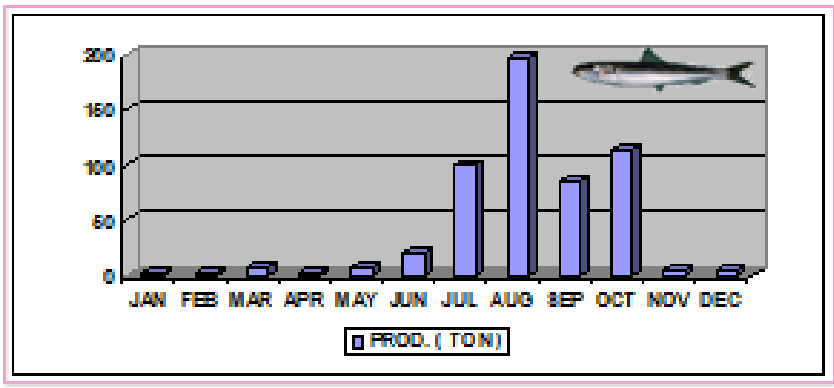

Gambar 3. Kecepatan vertikal rata-rata bulanan: (a) akhir musim timur (September); (b) musim barat (Desember). Temperatur permukaan laut rata-rata bulanan: (c) akhir musim timur (September); (d) musim barat (Desember). (e) Data tangkapan ikan bulanan di perairan selatan Jawa. 


\section{Antartahunan}

Fenomena antartahunan seperti El Niño dan La Niña mempengaruhi kekuatan upwelling yang terjadi pada musim timur di perairan selatan Jawa dan barat Sumatra. Pada penelitian ini, kekuatan upwelling tersebut ditentukan berdasarkan nilai temperatur permukaan laut (gambar tidak diperlihatkan). Pada kondisi El Niño, secara teoritis diketahui bahwa kedalaman termoklin di perairan Indonesia akan semakin dangkal, sehingga kekuatan upwelling akan lebih kuat dibandingkan kondisi normalnya. Sementara itu, pada kondisi La Niña, kedalaman termoklin akan semakin dalam dan menyebabkan pengurangan kekuatan upwelling di perairan Indonesia. Kekuatan upwelling yang direpresentasikan dengan nilai temperatur permukaan laut yang dihasilkan dari model hidrodinamika 3D HYCOM pada studi ini mengkonfirmasi studi-studi dari peneliti lainnya [8, 12, dan 9] bahwa kekuatan upwelling di perairan selatan Jawa akan menguat (melemah) pada fase El Niño (La Niña).

\section{Decadal}

Sinyal interdecadal seperti Pacific Decadal Oscillation (PDO) yang terjadi di Samudra Pasifik mempengaruhi frekuensi kejadian El Niño dan La Niña. Pada fase panas, fenomena El Niño lebih sering terjadi, sebaliknya pada fase dingin lebih sering terjadi fenomena La Niña. Gambar 4 memperlihatkan Indeks PDO yang menunjukkan adanya pola kejadian fase panas dan dingin yang berulang sekitar 30 tahunan (interdecadal). Berdasarkan pola interdecadal tersebut diduga kuat pada periode 2007 - 2037 adalah fase dingin, sehingga fenomena La Niña lebih sering terjadi. Oleh sebab itu, jika dikaitkan dengan dunia perikanan, dalam kurun waktu 2007 2037 intensitas upwelling di perairan Indonesia melemah dan berdampak pada menurunnya produksi perikanan. Penelitian lebih lanjut diperlukan untuk membuktikan adanya penurunan produksi perikanan pada periode 2007 - 2037 tersebut.

\section{- Pengaruh Perubahan Iklim}

Pemanasan global (global warming) yang saat ini sedang menjadi isu dunia diyakini berdampak terhadap perubahan iklim dan dinamika laut. [14] melaporkan bahwa perubahan iklim menyebabkan peningkatan frekuensi kejadian ENSO dari 3 - 7 tahun sekali, menjadi 1,5 - 3 tahun sekali. Selain itu, perubahan iklim akan memperkuat stratifikasi massa air di daerah tropis dan lint ang menengah dan akibatnya memperlemah proses percampuran (mixing), mengurangi kekuatan upwelling (supply nutrien ke permukaan berkurang), mengurangi jumlah phytoplankton, dan pada akhirnya menyebabkan pengurangan produksi perikanan [15]. Berdasarkan hasil simulasi model hidrodinamika 3D HYCOM jangka panjang, yaitu selama \pm 64 tahun (1950 2013), secara umum dampak pemanasan global terjadi juga di perairan Indonesia dan diketahui dalam kurun waktu 64 tahun tersebut telah terjadi kenaikan rata-rata suhu permukaan laut (SPL) $\pm 1,0{ }^{\circ} \mathrm{C}$ (Gambar 5). Dengan demikian, jika tren kenaikan SPL ini terus berlangsung, maka kekuatan upwelling akan semakin melemah dan akan mengurangi produksi perikanan.

\section{- Peranan Arus Lintas Indonesia (Arlindo) Terhadap Penguatan Upwelling di Perairan Selatan Jawa Timur}

Gambar 6a dan 6b memperlihatkan bahwa pada musim timur upwelling di perairan selatan Jawa Timur lebih kuat daripada di perairan selatan Jawa Barat, sedangkan kecepatan angin lebih kuat di perairan selatan Jawa Barat dibandingkan selatan Jawa Timur [16]. Adanya penguatan upwelling di perairan selatan Jawa Timur dicirikan dengan rendahnya SPL di daerah tersebut (Gambar 6a). Lebih lanjut, [16] memaparkan bahwa walaupun angin di selatan Jawa Timur lebih lemah, intensitas upwellingnya lebih kuat disebabkan eksistensi eddies yang terbentuk akibatnya adanya shear velocity dari Arlindo (Indonesian throughflow/ITF). Selain itu, berdasarkan RMS (root mean square) 
Analysis dari Sea Surface Height Anomaly (SSHA), [17] melaporkan bahwa variasi SSHA di perairan Jawa Timur paling tinggi tinggi dan ditunjukkan dengan fluktuasi perubahan tinggi muka air laut yang paling intens di daerah tersebut.

Berdasarkan penelitian lebih lanjut yang dilakukan oleh [18] ditemukan bahwa penguatan upwelling di perairan selatan Jawa Timur yang terkait dengan adanya eddies, tidak hanya disebabkan oleh shear velocity yang disebabkan Arlindo, tetapi juga oleh Arus Pantai Jawa (South Java Current/SJC). Skema umum pembentukan eddies tersebut diperlihatkan pada Gambar 6c. Secara umum

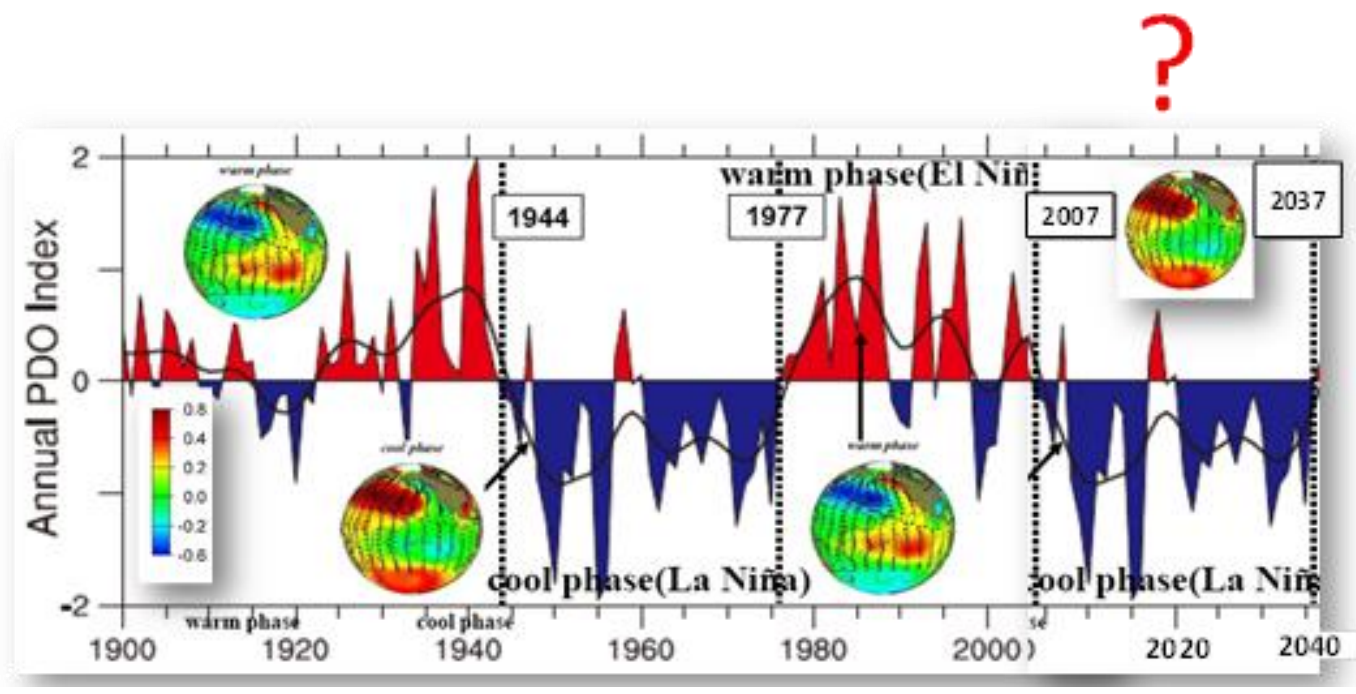

Gambar 4. Indeks Pacific Decadal Oscillation (PDO), (modifikasi dari: https://www.google.co.id/
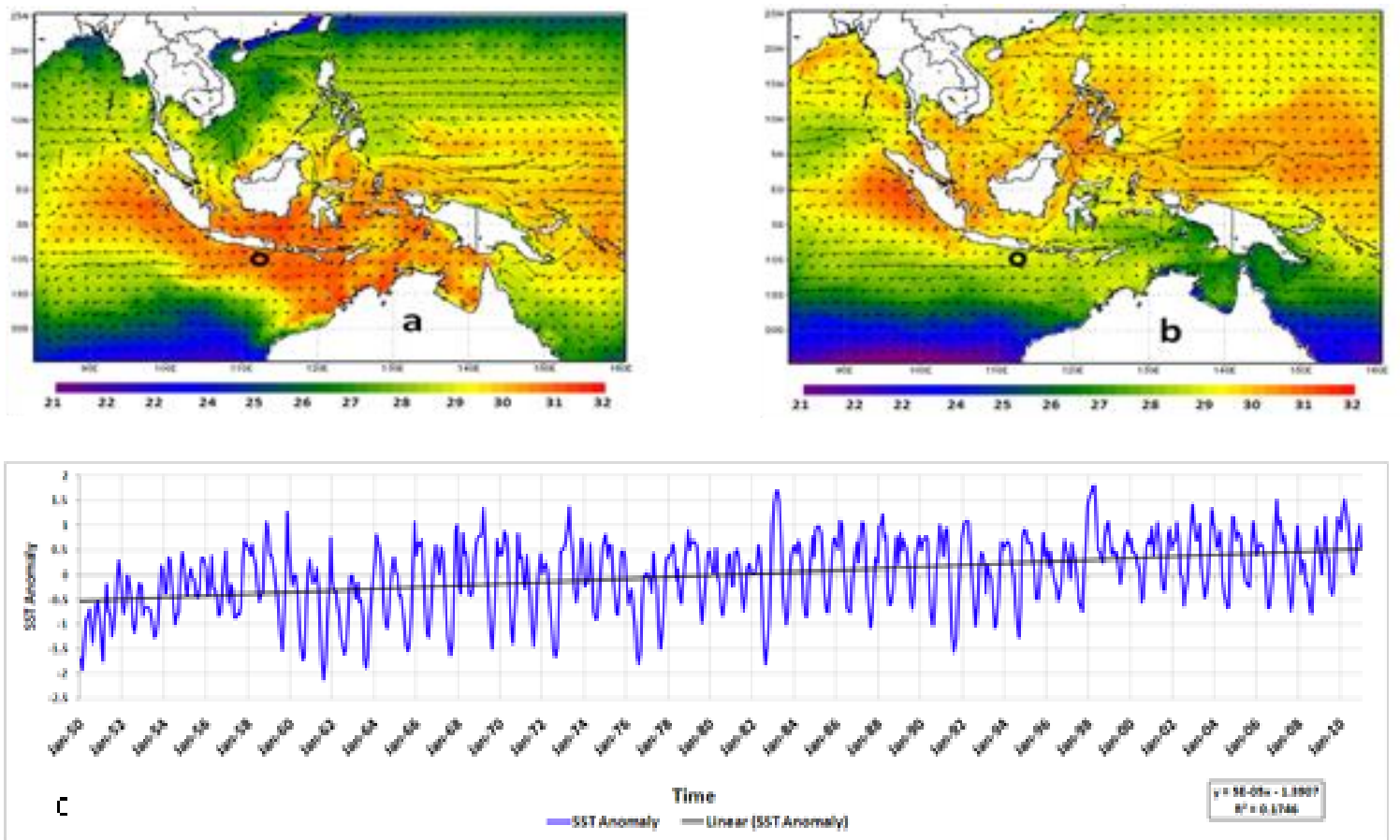

Gambar 5. Distribusi SPL pada kedalaman $\pm 10 \mathrm{~m}$ : (a) musim barat dan (b) musim timur; (c) Perubahan dan tren jangka panjang $(1950$ - 2013) sea surface temperature (SST) anomaly di selatan Jawa Timur (tanda "o"). 
eddies yang terbentuk di perairan selatan Jawa dapat berbentuk cyclonic (putaran warna biru pada Gambar 6c) maupun anticyclonic (putaran warna merah pada Gambar 6c). Di daerah offshore, eddies (Gambar 6c) juga dapat terbentuk karena adanya shear velocity dari ITF (Arlindo) dan South Equatorial Current (SEC). Dalam hal ini, cyclonic eddies diiringi dengan turunnya muka laut dan memicu timbulnya upwelling.

Eddies di perairan selatan Jawa ini dapat menjalar ke arah barat sebagai gelombang Rossby baik dalam bentuk cyclonic (searah jarum jam, di Belahan Bumi Selatan/BBS) maupun anticyclonic (berlawanan dengan arah jarum jam, di BBS), seperti diperlihatkan pada Gambar 7. Dinamika oseanografi dalam bentuk penjalaran gelombang Rossby ini berperan dalam pembangkitkan upwelling ketika eddies yang terbentuk tipenya cyclonic dan lebih lanjut akan berkontribusi pada kesuburan perairan dan peningkatan produksi perikanan. Informasi terkait lokasi, tipe eddies, dan kecepatan penjalaran dari gelombang Rossby di perairan selatan Jawa diperlukan dalam pengelolaan penangkapan ikan untuk mendapatkan hasil tangkapan yang optimal.
(2)

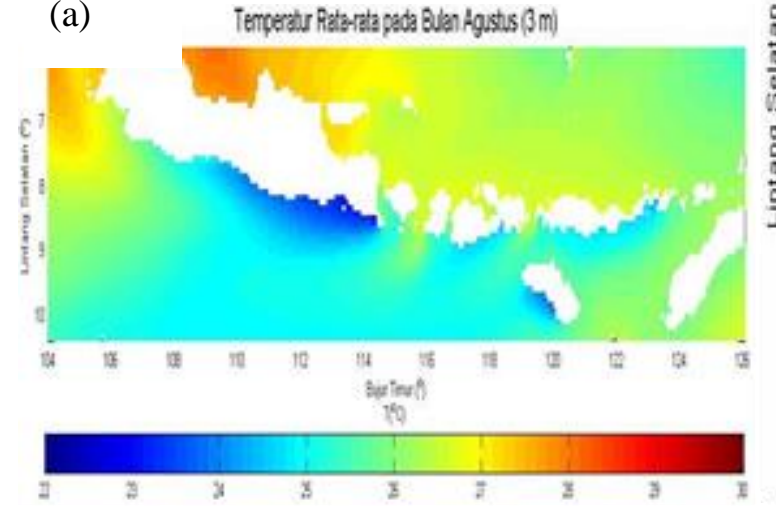

Sumber: [16] / Lidiawati (2014)

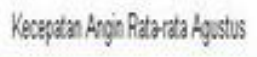

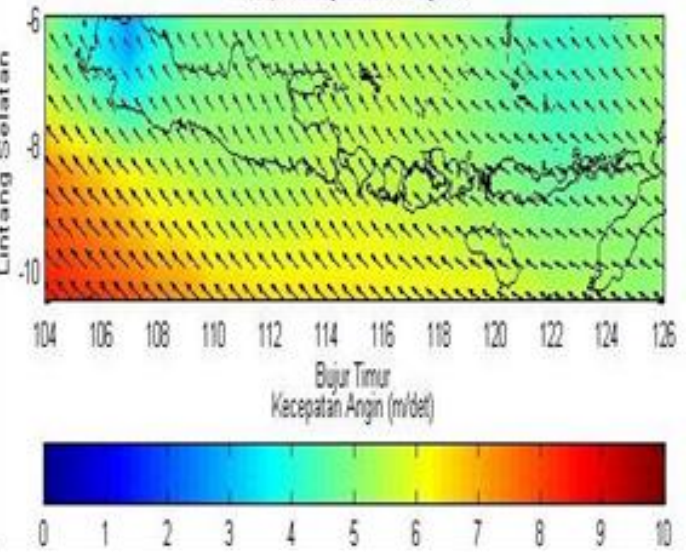

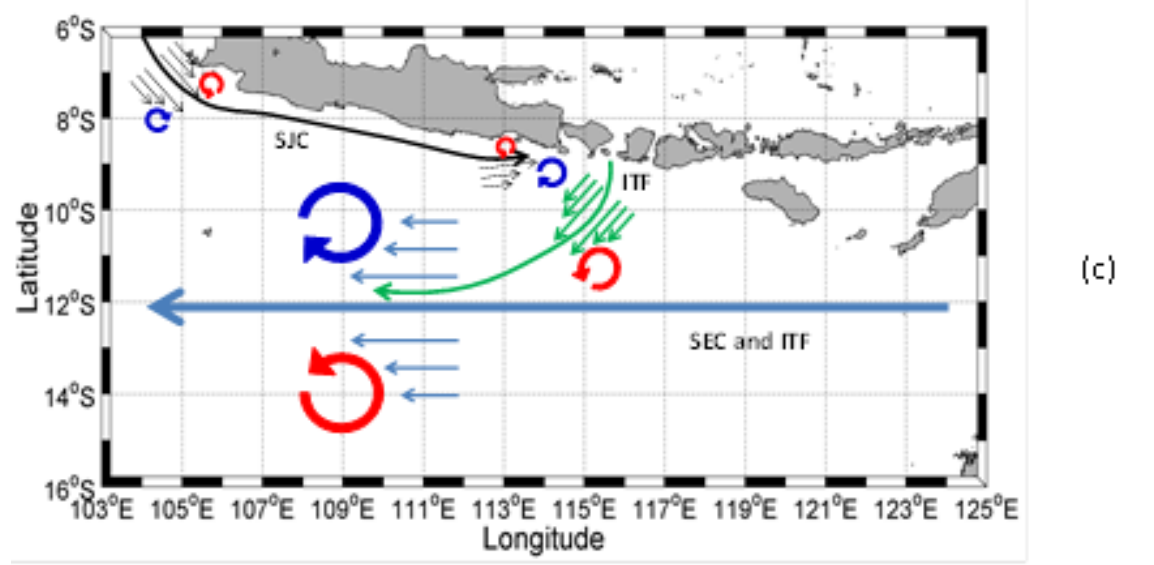

Gambar 6. (a) Distribusi SPL pada kedalaman $\pm 3 \mathrm{~m}$ yang menunjukkan adanya penguatan upwelling di perairan selatan Jawa Timur, (b) Kecepatan angin rata-rata di perairan selatan Jawa pada musim timur (Agustus); (c) Cyclonic (rotasi berwarna biru) dan anticyclonic eddies (rotasi berwarna merah) di perairan selatan Jawa yang disebabkan adanya shear velocity dari arus lintas Indonesia (ITF), South Java Current (SJV), dan South Equatorial Current (SEC). 

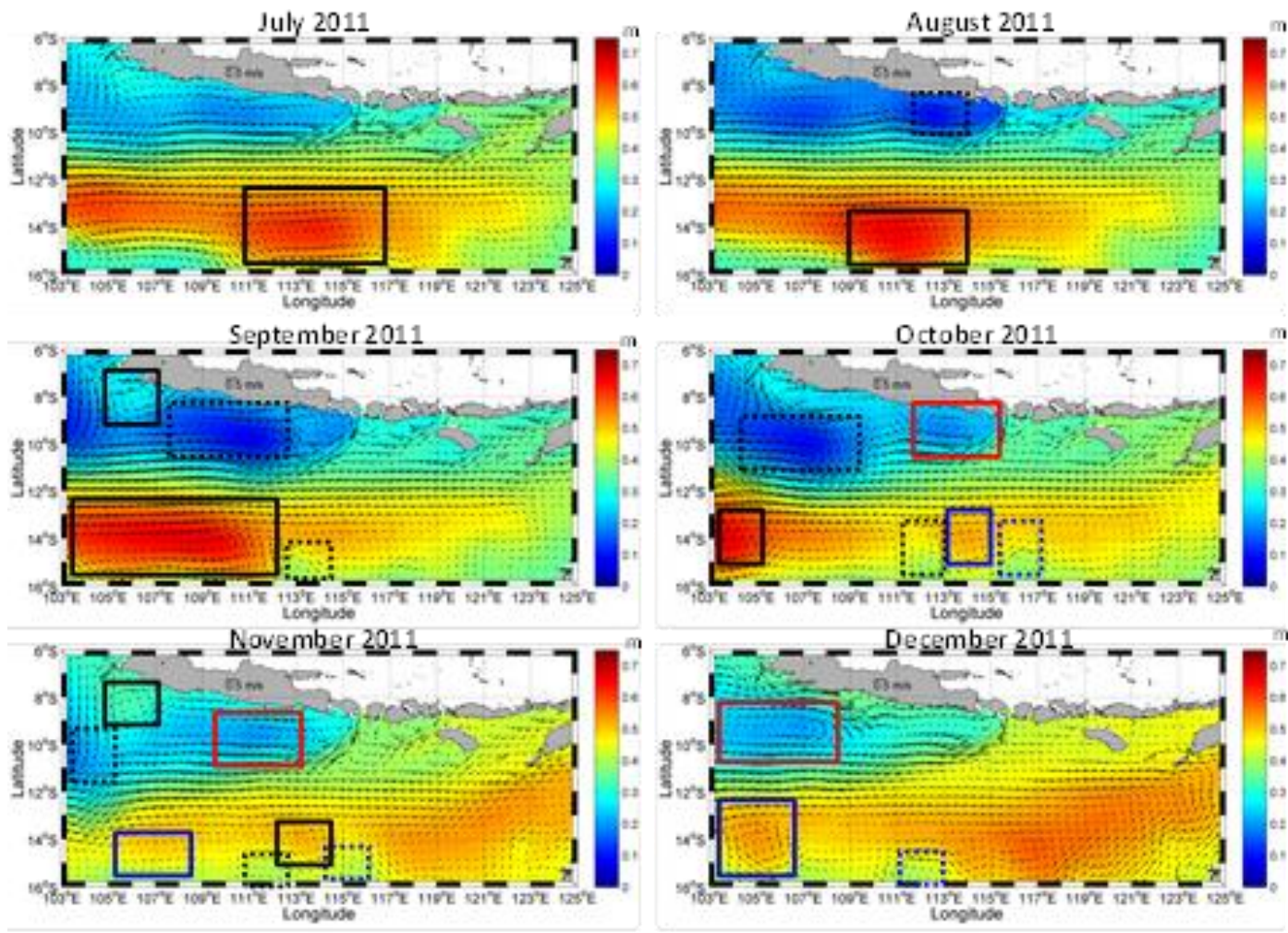

Gambar 7. Penjalaran gelombang Rossby di perairan selatan Jawa baik sebagai cyclonic eddies maupun anticyclonic eddies pada periode waktu Juli - Desember 2011.

\section{KESIMPULAN}

Kesuburan perairan yang terkait dengan kejadian upwelling di perairan Indonesia (khususnya perairan selatan Jawa) dipengaruhi oleh variabilitas intramusiman, musiman, antartahunan, dan interdecadal. Dalam skala musiman dan antartahunan, secara umum upwelling terjadi pada musim timur dan intensitasnya menguat ketika terjadi El Niño, sedangkan ketika La Niña intensitasnya melemah. Selain itu, variasi intramusiman seperti MJO dapat membangkitkan downwelling Kelvin wave yang menjalar di sepanjang pantai barat Sumatra dan selatan Jawa - Nusa Tenggara. Dari penelitian ini, ditemukan bahwa sebelum downwelling Kelvin wave tiba di sepanjang daerah studi, sekitar 10 - 13 hari sebelumnya akan didahului dengan kejadian penurunan muka laut berupa penjalaran upwelling Kelvin wave. Pola sinyal interdecadal dari PDO memperlihatkan adanya dugaan kuat bahwa periode 2007 -
2037 merupakan fase dingin yang mengindikasikan frekuensi kejadian La Niña lebih sering dibandingkan kejadian El Niño. Hal ini diduga berdampak pada pelemahan intensitas upwelling di perairan Indonesia dan penurunan produksi perikanan dalam kurun waktu 2007 - 2037.

Hasil simulasi model hidrodinamika jangka panjang (1950 - 2013) menunjukkan dampak pemanasan global terjadi juga di perairan Indonesia dan diketahui dalam kurun waktu tersebut telah terjadi kenaikan rata-rata suhu permukaan laut $\pm 1,0{ }^{\circ} \mathrm{C}$ (khususnya di perairan selatan Jawa) dan sebagai dampaknya akan memperlemah kekuatan upwelling. Parameter oseanografi yang lain, yaitu cyclonic eddies yang dapat membangkitkan upwelling terlihat eksistensinya di perairan selatan Jawa disebabkan adanya shear velocity dari Arlindo (ITF), arus pantai selatan Jawa (SJC), dan arus ekuator selatan (SEC). Lebih lanjut, eddies tersebut dapat menjalar ke arah barat sebagai gelombang Rossby. 


\section{UCAPAN TERIMA KASIH}

Terima kasih kami ucapkan kepada Kemenristekdikti yang telah mendanai penelitian ini melalui Penelitian Unggulan Perguruan Tinggi (PUPT) Ristekdikti 2016.

\section{DAFTAR PUSTAKA}

[1] B. Gafa, K. Wagiyo, dan B. Nugraha, "Hubungan antara suhu dan kedalaman mata pancing terhadap hasil tangkapan ikan Bigeye Tuna (Thunnus Obesus) dan Yellowfin Tuna (Thunus Albacores) dengan Tuna Longline di Perairan Laut Banda dan sekitarnya," Bal. Ris. Perik., Depar. Kel. dan Perik., 2002.

[2] T. Laevastu, dan I. Hela, "Fisheries oceanography," Fish. New Books Ltd., London. 236 p., 1970.

[3] K.N. Holland, R.W. Brill, dan R.K.C. Chang, "Horizontal and vertical movements of Yellowfin and Bigeye Tuna associated with fish agregating devices," Fish. Bull., vol. 88, hal. $493-$ 507. 1990.

[4] P.N. Sund, M. Blackburn, dan F. Williams, "Tuna and their environment in the Pacific Ocean," A Rev. Oceanogr. Biol. Ann. Rev., vol. 19, hal. 443 - 512. Aberdeen University Press, USA, 1981.

[5] K. H. Mann, dan J. R. N. Lazier, "Dynamics of marine ecosystems," Blackwell Scient. Public., 1991.

[6] A. L. Gordon, A. Ffield, dan A. G. Ilahude, "Thermocline of the Flores and Banda Seas," J. of Geophys. Res., vol. 99, no. C9, hal. 18.235-18.242, 1994.

[7] A.L. Gordon, dan R.D. Susanto, "Banda Sea surface-layer divergence," Oce. Dyn., vol. 52, hal. 2 - 10, 2001.
[8] Kunarso, S. Hadi, N.S. Ningsih, dan A. Supangat, "Upwelling dan fishing ground tuna di laut nusantara," $\mathrm{Bad}$. Penerb. Univ. Diponegoro. ISBN:978. 979.704.717.7, 2009.

[9] N.S. Ningsih, N. Rakhmaputeri, dan A.B. Harto, "Upwelling variability along the southern coast of Bali and in Nusa Tenggara Waters," Oce. Sci. Jour., vol. 48, no. 1, hal. 49-57, http://dx.doi.org/10.1007/s12601-0130004-3, 2013.

[10] A. Wallcraft, S. N. Carroll, K. A. Kelly, dan K. V. Rushing, "Hybrid coordinate ocean model (HYCOM), version 2.1, user's guide," Nav. Res. Lab., 2003.

[11] C. Zhang, "Madden-Julian oscillation," Rev. of Geoph., vol. 43, RG2003, doi: 10.1029/2004RG000158, 2005.

[12] R.D. Susanto, A.L. Gordon, dan Q. Zheng, "Upwelling along the coasts of Java and Sumatra and its relation to ENSO," J. Geophys. Res. Lett., vol. 28, no. 8, hal. 1599-1602, 2001.

[13] R.D. Susanto, dan J. Marra, "Effect of the 1997/98 El Niño on chlorophyll-a variability along the southern coasts of Java and Sumatera," Oceanogr., vol. 18, no. 4, hal. 24-127, 2005.

[14] M. Collins, "The El Niño-Southern Oscillation in the second Hadley centre coupled model and its response to greenhouse warming," J. of Clim., vol. 13, 2000.

[15] S.C. Doney, "Oceanography: Plankton in a warmer world," Natur., vol. 444, 2006.

[16] L. Lidiawati, "Dinamika dan variabilitas upwelling di perairan selatan Jawa Timur," Disert. Dok., Progr. Dokt. Sains Kebum., Inst. Tekn. Bandung, 2014. 
[17] F. Syamsudin, dan A. Kaneko, "Ocean variability along the southern coast of Java and Lesser Sunda Islands," J. of Oceanogr., vol. 69, no. 5, hal. 557-570, 2013.
[18] F. Hanifah, N.S. Ningsih, dan I. Sofian, "Dynamics of eddies in the southeastern tropical Indian Ocean," $J$. of Phys.: Conf. Ser. 739 (2016) 012042, ISSN: 1742-6596. DOI:10.1088/17426596/739/1/012042, 2016. 